\title{
Pengembangan perangkat pembelajaran dengan pendekatan pendidikan matematika realistik berorientasi pada minat dan prestasi
}

\author{
Ivone Marlinda ${ }^{1} *$, Ariyadi Wijaya ${ }^{2}$ \\ ${ }^{1}$ SMP Negeri 6 Satu Atap Kepil. Dsn. Krajan, Kel. Gadingsukuh, Kec. Kepil, Wonosobo, Indonesia. \\ ${ }^{2}$ Jurusan Pendidikan Matematika, Universitas Negeri Yogyakarta. Jalan Colombo No. 1, \\ Karangmalang, Yogyakarta 55281, Indonesia. \\ * Corresponding Author. E-mail: marlinda179@gmail.com \\ Received: 8 September 2018; Revised: 17 September 2018; Accepted: 21 September 2018
}

\begin{abstract}
Abstrak
Penelitian ini bertujuan untuk menghasilkan perangkat pembelajaran untuk siswa kelas VIII SMP dengan pendekatan pendidikan matematika realistik yang valid, praktis, dan efektif. Perangkat Pembelajaran ini terdiri atas RPP dan LKS yang berorientasi pada minat dan prestasi belajar siswa. Jenis penelitian ini adalah penelitian pengembangan (Research \& Development). Penelitian ini mengembangkan perangkat pembelajaran dengan menggunakan model pengembangan 4D (Define, Design, Develop, Disseminate). Subjek uji coba penelitian adalah 21 siswa. Instrumen penelitian yang digunakan terdiri dari lembar validasi, lembar penilaian kepraktisan siswa, lembar penilaian kepraktisan guru dan instrumen penilaian. Analisis data dilakukan dengan mengkonversi total skor data kuantitatif yang diperoleh menjadi data kualitatif skala lima. Kevalidan perangkat mencapai kriteria sangat baik. Kepraktisan pada uji coba lapangan mencapai kategori sangat baik untuk penilaian guru dan mencapai kategori baik untuk penilaian siswa. Keefektifan perangkat yang dikembangkan terlihat dari (1) persentase ketuntasan tes prestasi belajar mencapai 80,95\%; (2) berdasarkan hasil penilaian angket, persentase siswa yang memiliki minat minimal pada kategori tinggi mencapai $85,71 \%$.
\end{abstract}

Kata kunci: pengembangan, perangkat pembelajaran, pendidikan matematika realistik, minat, prestasi

\section{Developing a learning set with realistic mathematics education approach oriented to the interest and achievement}

\begin{abstract}
This research aimed to develop a learning set for the eight grade students of junior high school based on realistic mathematics education which was valid, practical, and effective. The instructional material consists of lesson plans and student's worksheets, which were oriented to the interest and student's learning achievements. This was a research and development study. It developed learning set using the 4-D development model (Define, Design, Develop and Disseminate). The subjects of this research involved 21 students. The research instrument included validation sheets, student practicality assessment sheets and assessment instrument. The data analysis was done by converting the total score of the quantitative data into qualitative data in rating scale of five. The validity of learning set reached very good criteria. The practicality on field trials reached very good category from teacher assessment and good category from students' assessment. Effectiveness of learning set were developed by (1) the percentage of classical mastery of learning achievements test reached $80.95 \%$; (2) based on the result of the questioner the percentage of the student's interest who have reached the high minimum category score was $85.71 \%$.
\end{abstract}

Keywords: development, learning set, realistic mathematics education, interest, achievement

How to Cite: Marlinda, I., \& Wijaya, A. (2018). Pengembangan perangkat pembelajaran dengan pendekatan pendidikan matematika realistik berorientasi pada minat dan prestasi. Pythagoras: Jurnal Pendidikan Matematika, 13(1), 76-87. doi:http://dx.doi.org/10.21831/pg.v13i1.21171

d.

http://dx.doi.org/10.21831/pg.v13i1.21171 


\section{PENDAHULUAN}

Matematika merupakan mata pelajaran yang sangat penting. Melalui pembelajaran matematika, diharapkan peserta didik memiliki kemampuan berpikir logis, analitis, sistematis, kritis, dan kreatif, serta kemampuan bekerja sama. Berbekal kemampuan tersebut diharapkan peserta didik tumbuh dan berkembang menjadi pribadi yang mampu bertahan hidup pada keadaan yang selalu berubah, tidak pasti dan kompetitif (Permendikbud, 2014). Lebih lanjut dalam Standar Isi (Permendiknas, 2006, p.346) dijelaskan bahwa matematika merupakan salah satu mata pelajaran pokok yang diberikan dengan tujuan agar peserta didik memiliki sikap menghargai kegunaan matematika dalam kehidupan, yaitu memiliki rasa ingin tahu, perhatian dan minat dalam mempelajari matematika, serta sikap ulet dan percaya diri dalam memecahkan masalah.

Berdasarkan tujuan pembelajaran tersebut, segi afektif juga menjadi target yang harus dicapai. Dalam kegiatan belajar yang dilaksanakan ada beberapa hal yang dapat mendorong siswa, salah satunya adalah minat. Minat memiliki peran penting dalam pembelajaran, seperti yang dinyatakan oleh Baumert dan Schanabel, Schiefele, et al (Frenzel, Goetz, Pekrun, \& Watt, 2010, p.508) bahwa "interest is an important force determining the quality of learning". Minat juga besar sekali pengaruhnya terhadap kegiatan seseorang, orang akan belajar atau mengerjakan sesuatu dengan baik jika ia berminat dan tidak akan belajar dengan baik jika ia tidak berminat.

Elliott, Kratochwill, Cook, dan Travers (2000, p.349) menyatakan "interest is similiar and related to curiosity. Interest is an enduring characteristic expressed by a relationship between a person and particular activity or object", artinya minat berhubungan dengan keingintahuan dan merupakan sesuatu yang menghubungkan seseorang dengan kegiatan khusus yang disenangi sehigga membentuk karakteristik yang tetap. Senada dengan pendapat Elliot, Scraw dan Lehman (Schunk, Pintrich \& Meece, 2010, p.210) menyatakan bahwa "interest refers to the liking and willfull engangement in activity", artinya minat merupakan perasaan senang dan pergerakan yang disengaja dalam aktivitas. Pendapat lain yang dikemukakan oleh Nitko dan Brookhart (2011, p.430) menyatakan bahwa "interests, on the other hand, are preferences for specific types of activities when a person is not under external pressure". Menurut pendapat tersebut minat merupakan pilihan terhadap bentuk- bentuk tertentu dari suatu aktivitas ketika seseorang tidak berada dalam tekanan dari luar dirinya.

Selanjutnya menurut Elliot, et al (2000, p.349) ada lima langkah yang dapat dilakukan oleh guru untuk menumbuhkan dan memfasilitasi pengembangan minat, yaitu: (1) mengajak siswa untuk berpartisipasi dalam kegiatan yang bermakna dan berhubungan dengan dunia luar kelas; (2) memberikan kegiatan yang melibatkan kebutuhan siswa dan memberikan tantangan sesuai dengan tahapan perkembangan mereka; (3) memberikan kesempatan kepada siswa untuk memiliki peran utama dalam mengevaluasi pekerjaan mereka sendiri dan dalam memantau kemajuan mereka; (4) memfasilitasi integrasi dan penggunaan pengetahuan; (5) memberi kesempatan siswa untuk belajar dan bekerja sama dengan siswa lain.

Pada penelitian ini, tujuan pembelajaran yang akan dibahas difokuskan pada minat siswa terhadap matematika. Ketercapaian tujuan tersebut tidak terlepas dari proses pembelajaran di kelas yang melibatkan peran guru. Guru sebagai fasilitator harus dapat menciptakan pembelajaran yang lebih kreatif dan inovatif. Haylock dan Thangata (2007, p.35) mengemukakan "the central idea of constructivism is that learning is an active process in wich learners construct new ideas or concept based upon their current a prior knowledge. Knowledge is not waiting 'out there' to be acquired, but is constructed". Lebih lanjut, Gravemeijer (1994, p.2) menegaskan bahwa belajar matematika adalah membuat hubungan antara pengetahuan yang telah dimiliki siswa dengan yang akan dipelajarinya. Belajar matematika dengan hanya mengingat rumus dan menghafal konsep-konsep tanpa pemahaman adalah tidak bermakna. Oleh karena itu, pembelajaran matematika harus memberikan ruang dan kesempatan bagi siswa untuk terlibat aktif dalam proses pembelajaran dalam rangka membangun konsep matematika.

Untuk mencapai kondisi pembelajaran tersebut, guru diharapkan mampu merencanakan pembelajaran sebaik mungkin. Perencanaan kegiatan pembelajaran dilakukan dengan menyusun perangkat pembelajaran. Perangkat pembelajaran yang dimaksud berupa Rencana Pelaksanaan Pembelajaran (RPP) dan Lembar Kegiatan Siswa (LKS). Perencanaan RPP sebelum proses pembelajaran merupakan hal yang wajib dilakukan oleh guru. Hal ini sesuai dengan Permendikbud Nomor 65 Tahun 2013 tentang Standar Proses 
Pendidikan Dasar dan Menengah yang menyatakan bahwa setiap pendidik pada satuan pendidikan berkewajiban menyusun Rencana Pelaksanaan Pembelajaran lengkap dan sistematis agar pembelajaran berlangsung secara interaktif, inspiratif, menyenangkan, menantang, efisien, memotivasi siswa untuk berpartisipasi aktif, serta memberikan ruang yang cukup bagi prakarsa, kreativitas, dan kemandirian sesuai dengan bakat, minat dan perkembangan fisik serta psikologis siswa.

Selain membuat rencana dalam kegiatan pembelajaran, agar dapat menanamkan konsep matematika dengan lebih baik dan dapat melibatkan siswa dalam proses pembelajaran, guru memerlukan Lembar Kerja Siswa (LKS). LKS merupakan bahan ajar cetak berupa lembaran kertas yang berisi materi, ringkasan, dan petunjuk pelaksanaan tugas pembelajaran yang harus dikerjakan siswa, yang mengacu pada kompetensi dasar yang harus dicapai. Penggunaan LKS di kelas bertujuan untuk memudahkan siswa dalam melakukan proses belajar.

Pada kenyataannya, berdasar hasil wawancara tidak terstruktur dengan guru matematika di SMP Negeri 6 Satu Atap Kepil guru masih kurang berminat untuk membuat RPP. RPP yang digunakan adalah RPP yang dikembangkan dari MGMP dan RPP dari tahun sebelumnya. RPP yang dibuat hanya sekedar formalitas dan tidak menggambarkan kegiatan yang melibatkan aktivitas siswa. Pelaksanaan pembelajaran dengan menggunakan LKS di SMP Negeri 6 Satu Atap Kepil masih belum optimal. Hal ini terlihat dari LKS yang digunakan berisi ringkasan materi dan kumpulan soal-soal yang cenderung monoton. Siswa hanya berlatih menjawab soal, tidak menekankan pada pengkomunikasian pengalaman atau fenomena langsung yang melibatkan siswa dalam proses belajar mengajar. Hal ini menyebabkan siswa kurang berminat dalam kegiatan belajar mengajar. Selain itu, menurut Sembiring (2010, p.15) di Indonesia masih kurang bahan ajar yang memberikan peluang bagi siswa untuk mengembangkan kreativitasnya.

Berdasarkan kondisi yang demikian, pembelajaran yang dilakukan belum memenuhi standar yang ditentukan. Hasil observasi pra penelitian di SMP Negeri 6 Satu Atap Kepil masih banyak siswa yang kurang antusias dengan matematika, hal ini tampak dari kurangnya respon yang diberikan siswa dalam pembelajaran. Kondisi demikian diduga karena siswa kurang berminat terhadap matematika. Hasil penelitian menunjukkan adanya penurunan minat belajar matematika di tingkat sekolah menengah (Frenzel, et al, 2010, p.508). Selain itu, dari hasil observasi pra penelitian, terlihat bahwa minat belajar matematika siswa masih rendah. Hal ini dapat dilihat ketika guru sedang menjelaskan materi, siswa cenderung tidak serius saat mengikuti pembelajaran matematika, berbicara sendiri dengan teman sebangkunya, atau main-main dengan teman sebangkunya. Apabila guru bertanya kepada siswa tentang materi yang baru saja diajarkan, kebanyakan siswa diam saja dan tidak merespon pertanyaan dari guru. Selain itu, siswa tidak membawa perlengkapan belajar matematika dan tidak mempunyai ketertarikan untuk dapat menyelesaikan soal matematika. Dengan demikian, diperlukan upaya untuk mempertahankan atau meningkatkan minat belajar matematika.

Selain minat, kenyataan di lapangan menunjukkan prestasi belajar siswa dalam matematika juga masih belum optimal. Hal ini dapat dilihat dari hasil tes Trend in International Mathematics and Sciences Study (TIMSS) yang diikuti oleh siswa kelas VIII SMP. Hasil evaluasi TIMSS 2011, capaian rata-rata peserta Indonesia adalah 386 yang berarti berada pada level rendah. Capaian rata-rata peserta Indonesia pada TIMSS 2011 mengalami penurunan dari capaian rata-rata pada TIMSS 2007 yaitu 397 (Mullis, Martin, Foy, \& Arora, 2012). Rendahnya prestasi matematika dalam skala nasional dapat dilihat dari hasil ujian nasional salah satunya di provinsi Jawa Tengah. Berikut data rata-rata nilai matematika provinsi Jawa Tengah.

Tabel 1. Rata-Rata Nilai Matematika Provinsi Jawa Tengah

\begin{tabular}{cc}
\hline Tahun & Rata-rata Nilai \\
\hline $2011 / 2012$ & 6,49 \\
$2012 / 2013$ & 5,16 \\
$2013 / 2014$ & 5,53 \\
$2014 / 2015$ & 4,74 \\
\hline & (Sumber: Balitbang Kemdikbud)
\end{tabular}

Dari Tabel 1 tersebut terlihat bahwa nilai rata-rata matematika provinsi Jawa Tengah mengalami penurunan. Pada tahun pelajaran 2011/2012 rata-rata nilai matematika 6,49 turun 1,33 menjadi 5,16 pada tahun pelajaran 2012/ 2013 , kemudian naik 0,37 pada tahun pelajaran 2013/2014 menjadi 5,53 dan pada tahun pelajaran 2014/2015 turun 0,79 menjadi 4,74. Rendahnya prestasi matematika juga terjadi di SMP Negeri 6 Satu Atap Kepil. Berdasarkan hasil ujian nasional tahun 2015 nilai rata-rata mata pelajaran matematika lebih rendah dibandingkan 
nilai rata-rata mata pelajaran lain. Berikut laporan hasil ujian nasional SMP Negeri 6 Satu Atap Kepil.

Tabel 2. Laporan Hasil Ujian Nasional Tahun Ajaran 2014/2015 SMP N 6 Satu Atap Kepil

\begin{tabular}{cc}
\hline Mata Pelajaran & Rata-rata \\
\hline Bahasa Indonesia & 72,48 \\
Bahasa Inggris & 50,33 \\
Matematika & 45,12 \\
IPA & 60,00 \\
\hline
\end{tabular}

Salah satu upaya yang dilakukan untuk mengatasi rendahnya minat dan prestasi belajar adalah dengan merancang kegiatan yang berpusat pada siswa (student centre). Menurut guru di SMP Negeri 6 Satu Atap Kepil seringkali kegiatan pembelajaran masih berpusat pada guru. Proses pembelajaran yang dilakukan seharusnya memberikan ruang lebih banyak kepada siswa untuk membangun pengetahuan baru berdasar pengetahuan yang telah diperoleh sebelumnya. Pengajaran dimulai dan hal yang konkrit dilanjutkan ke hal yang abstrak, dari hal yang mudah ke hal yang sulit dan dari hal yang sederhana ke hal yang kompleks.

Pembelajaran matematika sebaiknya dikaitkan dengan pengalaman kehidupan nyata siswa sehingga apa yang dipelajarinya menjadi bermakna dan dirasakan bermanfaat dalam kehidupan sehari-hari. Hal ini sesuai dengan yang dikemukakan oleh Freudenthal (Van den HeuvelPanhuizen, 2001) "mathematics must be connected to reality, stay close to children and be relevant to society, in order to human value" pernyataan tersebut bermakna matematika seharusnya berhubungan dengan kenyataaan seharihari, dekat dengan anak dan relevan dengan lingkungan. Salah satu pendekatan pembelajaran matematika yang mengaitkan pengalaman kehidupan nyata siswa dengan pembelajaran matematika adalah Realistic Mathematics Education $(R M E)$ atau di Indonesia dikenal dengan istilah Pendidikan Matematika Realistik (PMR). Nugraheni \& Sugiman (2013, p.104) mengemukakan bahwa matematika realistik adalah sebuah pendekatan yang mempunyai peluang untuk diterapkan dalam upaya perbaikan mutu pendidikan matematika di Indonesia. Hasil penelitian Zaini dan Marsigit (2014) menunjukkan bahwa pembelajaran dengan PMR lebih baik dari pembelajaran konvensional ditinjau dari penalaran dan komunikasi matematis siswa. Menurut Webb, Van der Kooij \& Geist (2011, p.48), RME menawarkan jalan untuk mendukung pemahaman siswa dari suatu hal yang abstrak ke konkrit. Realistik tidak hanya berarti mempunyai makna benda nyata dalam lingkungan (fisik) melainkan juga merupakan benda non fisik yaitu situasi yang diketahui sebelumnya (Van den Heuvel-Panhuizen, 1996). Pendekatan realistik dilandasi oleh pemikiran Freundenthal yang mengatakan bahwa matematika adalah aktivitas manusia sehingga pembelajaran matematika dipandang sebagai suatu proses dan bukan sebagai barang jadi. Pembelajaran yang berorientasi PMR bersifat mengutamakan penemuan kembali, pengenalan konsep melalui masalah kontekstual, hal-hal yang konkrit atau dari lingkungan siswa dengan proses matematisasi oleh siswa dengan mengkonstruksikan idenya sendiri.

Sugiman dan Kusumah (2010, p.43) menyatakan bahwa dalam PMR, masalah-masalah nyata dijadikan sebagai titik awal dalam pembelajaran yang selanjutnya dimanfaatkan oleh siswa dalam melakukan proses matematisasi dam pengembangan model matematika. Zulkardi (2002, p.30) menambahkan bahwa titik awal pembelajaran harus bersifat pengalaman nyata bagi siswa, yang memungkinkan mereka mengarah ke situasi kontekstual. Dengan demikian, masalah kontekstual dapat digunakan sebagai titik awal dalam pembelajaran matematika untuk membantu siswa dalam menemukan konsep. Konsep matematika yang muncul dari masalah kontekstual merupakan salah satu ciri dari matematika relaistik.

Gravemeijer (1994, p.90) mengemukakan bahawa ada tiga prinsip utama dalam PMR, yaitu: guided reinvention and progressive mathematizing, didactical phenomenology dan selfdevelopment models. Treffers (Cowan, 2006, p.20) merumuskan lima karakteristik PMR, yaitu: penggunaan konteks yang "nyata" bagi para siswa, penggunaan model-model untuk membantu siswa mencapai pemahaman yang lebih tinggi, pemanfaatan hasil kontruksi siswa, interaktivitas dan keterkaitan. Berdasarkan prinsip dan karakteristik PMR, maka langkah-langkah pembelajaran pada kegiatan inti dalam penelitian ini yaitu: memahami masalah kontekstual, mendeskripsikan masalah kontekstual, menyelesaikan masalah kontekstual, membandingkan dan mendiskusikan jawaban, dan menyimpulkan.

Berdasarkan uraian tersebut, peneliti tertarik untuk mengembangkan perangkat pembelajaran dengan pendekatan pendidikan matematika realistik dengan harapan dapat memberikan kontribusi bagi pembelajaran matematika. Selain itu, pemillihan pendekatan PMR diharapkan 
dapat memfasilitasi pembelajaran yang bermakna bagi siswa yang mampu menumbuhkan minat siswa dan meningkatkan prestasi belajar siswa. Dengan demikian tujuan penelitian ini adalah untuk untuk menghasilkan perangkat pembelajaran untuk siswa kelas VIII SMP dengan pendekatan pendidikan matematika realistik yang valid, praktis, dan efektif.

\section{METODE}

Jenis penelitian ini merupakan penelitian pengembangan (Research and Development). Pengembangan ini bertujuan mengembangkan produk berupa perangkat pembelajaran matematika SMP Kelas VIII semester 2 dengan pendekatan Pendidikan Matematika Realistik yang terdiri atas rencana pelaksanaan pembelajaran (RPP) dan lembar kerja siswa (LKS). Penelitian ini juga dimaksudkan untuk menghasilkan produk dan mengetahui kualitas perangkat pembelajaran yang dikembangkan dari aspek kevalidan, kepraktisan dan keefektifan yang berorientasi pada minat dan prestasi belajar siswa.

Penelitian ini dilaksanakan di SMP Negeri 6 Satu Atap Kepil pada tanggal 1 April 2016 sampai dengan 20 Mei 2016. Kegiatan uji coba lapangan dilaksanakan selama 10 kali pertemuan. Subjek uji coba dalam penelitian ini adalah guru dan siswa SMP Negeri 6 Satu Atap Kepil. Subjek uji coba pada penelitian ini terbagi menjadi dua, yaitu subjek uji coba terbatas dan subjek uji coba lapangan. Subjek uji coba terbatas adalah enam siswa kelas IX di SMP Negeri 6 Satu Atap Kepil yang terdiri atas dua siswa berkemampuan rendah, dua siswa berkemampuan sedang, dan dua siswa berkemampuan tinggi. Untuk subjek uji coba lapangan dalam penelitian ini adalah 21 siswa kelas VIII SMP Negeri 6 Satu Atap Kepil. Materi yang diujicobakan pada penelitian ini adalah KD 5.1, KD 5.2 dan KD 5.3 tentang bangun ruang sisi datar.

Model pengembangan yang digunakan dalam penelitian ini yaitu model pengembangan 4-D (Thiagarajan, Semmel \& Semmel, 1974, p.6) yang meliputi tahap pendefinisian (define), perancangan (design), pengembangan (develop), dan diseminasi (disseminate). Model pengembangan yang telah dimodifikasi ditunjukkan dalam Gambar 1.

Tahap Define (Pendefinisian) dilakukan untuk menentukan tujuan dan permasalahan sebagai patokan dalam penyusunan perangkat pembelajaran. Pada tahap ini dilakukan beberapa hal sebagai berikut: (a) analisis awal-akhir yang bertujuan untuk mengidentifikasi masalah dan fakta yang dijadikan dasar dalam pengembangan perangkat pembelajaran, (b) analisis siswa dilakukan untuk mengetahui karakteristik siswa. Hasil analisis siswa ini diperoleh dari informasi guru sekolah yang bersangkutan, (c) analisis konsep bertujuan untuk mengidentifikasi, merinci, dan menyusun materi secara sistematis bagian-bagian utama yang relevan yang akan menghasilkan suatu peta konsep untuk pengembangan perangkat pembelajaran, (d) analisis tugas dilakukan untuk mendapatkan rincian mengenai tugas-tugas yang akan diberikan kepada siswa dalam pembelajaran, (e) Spesifikasi Tujuan Pembelajaran bertujuan untuk mengidentifikasi indikator-indikator ketercapaian hasil belajar siswa.

Tahap Design (Perancangan) dilakukan kegiatan yaitu: (a) penyusunan tes kriteria , (b) pemilihan media, dilakukan untuk menentukan media yang tepat dalam pembelajaran, (c) pemilihan format, (d) rancangan awal, kegiatan pada tahap ini adalah merancang desain awal dari perangkat pembelajaran yang dikembangkan berdasarkan pada hasil yang telah didapatkan pada tahap pendefinisian sampai pada tahap pemilihan format.

Tahap pengembangan (development) diawali dengan menyusun perangkat pembelajaran berupa Rencana Pelaksanaan Pembelajaran (RPP) dan Lembar Kegiatan Siswa (LKS). Setelah perangkat tersebut selesai disusun, langkah selanjutnya adalah melakukan proses validasi ahli. Proses validasi dilakukan dengan menggunakan lembar validasi yang sebelumnya juga telah dinilai oleh seorang ahli. Setelah proses validasi dan revisi produk pengembangan, maka proses selanjutnya yang dilakukan adalah melakukan uji coba terbatas dan uji coba lapangan.

Dalam penelitian ini, teknik pengumpulan data terdiri atas dua, yaitu: non tes dan tes. Teknik non tes meliputi lembar validasi, lembar penilaian, dan angket. Teknik pengumpulan data dengan tes berupa tes pilihan ganda. Pada penelitian ini, peneliti menggunakan beberapa instrumen untuk mengetahui kevalidan, kepraktisan, dan keefektifan produk yang dikembangkan. 
Pythagoras, 13 (1), 2018 - 81

Ivone Marlinda, Ariyadi Wijaya

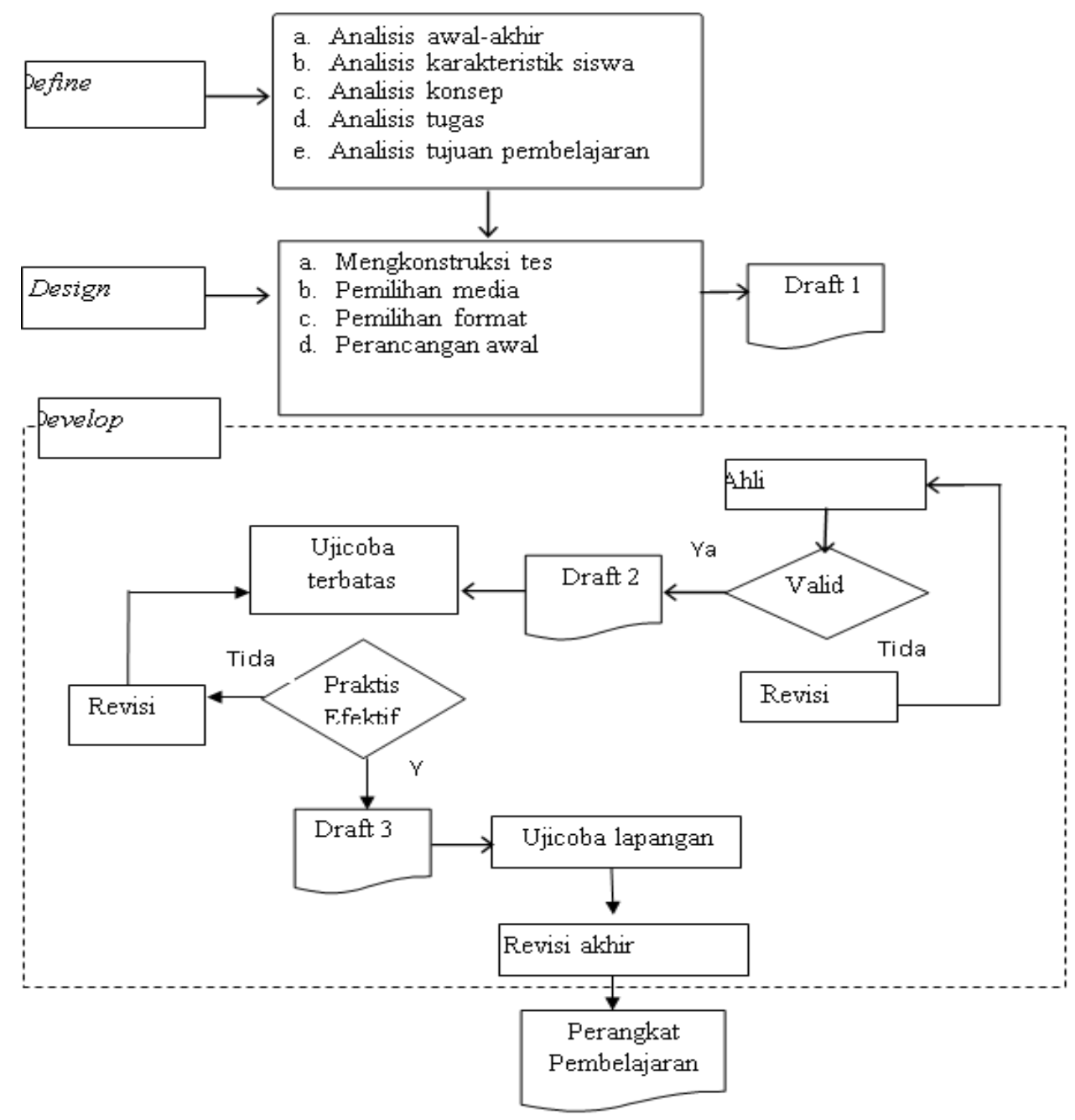

Gambar 1. Alur Penelitian Pengembangan

Instrumen yang digunakan untuk mengukur kevalidan perangkat pembelajaran meliputi lembar validasi RPP dan lembar validasi LKS. Kriteria penilaian dalam lembar validasi yang dikembangkan terdiri atas 5 skala penilaian, yaitu: tidak baik (skor 1), kurang baik (skor 2), cukup baik (skor 3), baik (skor 4), dan sangat baik (skor 5). Instrumen penilaian kepraktisan perangkat pembelajaran meliputi lembar penilaian kepraktisan oleh guru dan siswa. menggunakan perangkat yang dikembangkan. Instrumen yang digunakan untuk menilai keefektifan perangkat pembelajaran yang dikembangkan meliputi tes dan angket minat.

Data yang diperoleh dianalisis untuk menjawab apakah perangkat pembelajaran yang dikembangkan memenuhi syarat kevalidan, kepraktisan, dan keefektifan. Jika ketiga syarat tersebut terpenuhi maka akan diperoleh produk perangkat pembelajaran matematika yang berkualitas. Data yang berupa komentar, saran, revisi, dan hasil observasi selama proses uji coba dianalisis secara deskriptif kualitatif dan disimpulkan sebagai masukan untuk merevisi produk yang dikembangkan. Sedangkan, data yang diperoleh melalui lembar validasi perangkat, lembar penilaian kepraktisan oleh guru dan siswa, dan angket minat siswa dianalisis secara statistika deskriptif kuantitatif. Data yang mula-mula berupa skor kemudian diubah menjadi data kualitatif dengan skala lima dengan acuan rumus yang diadaptasi dari Widoyoko (2014, p.238) seperti pada Tabel 3.

Tabel 3. Kriteria Konversi Data Kuantitatif ke Data Kualitatif

\begin{tabular}{cc}
\hline Interval & Kriteria \\
\hline$X>\bar{X}_{i}+1,8$ Sbi & Sangat Baik \\
$\bar{X}_{i}+0,6 S b i<X \leq \bar{X}_{i}+1,8 S b i$ & Baik \\
$\bar{X}_{i}-0,6 S b i<X \leq \bar{X}_{i}+0,6 S b i$ & Cukup Baik \\
$\bar{X}_{i}-1,8 S b i<X \leq \bar{X}_{i}-0,6 S b i$ & Kurang Baik \\
$X \leq \bar{X}_{i}-1,8 S b i$ & Sangat Kurang \\
\hline
\end{tabular}

Keterangan:

$\boldsymbol{X}=$ Skor empirik

$\overline{\mathrm{X}}_{\mathrm{i}}=$ Rata-rata ideal 
$=\frac{1}{2}($ skor maks + skor min $)$

$\boldsymbol{S} \boldsymbol{b} \boldsymbol{i}=$ Standar deviasi ideal

$=\frac{1}{6}($ skor maks ideal - skor min ideal $)$

Skor maks $=\Sigma$ butir kriteria $\times$ skor tertinggi

Skor min $=\Sigma$ butir kriteria $\times$ skor terendah

Analisis kevalidan perangkat pembelajaran dimaksudkan untuk mengetahui sejauh mana perangkat pembelajaran yang dikembangkan Rencana Pelaksanaan Pembelajaran (RPP) dan Lembar Kerja Siswa (LKS) memenuhi kriteria valid berdasarkan penilaian ahli dengan menggunakan lembar validasi. Skor penilaian yang diperoleh dari para ahli melalui lembar validasi dijumlahkan dan hasilnya dikonversi menjadi data kualitatif skala lima. Instrumen penilaian dikatakan valid jika rata-rata penilaian dari para ahli minimal berada pada kategori "Baik". Hasil Kategori penilaian kevalidan perangkat disajikan pada Tabel 4 dan kevalidan instrumen disajikan dalam Tabel 5.

Tabel 4. Kategori Penilaian Kevalidan Perangkat

\begin{tabular}{ccc}
\hline Komponen & Interval & Kategori \\
\hline & $\bar{X}>100,8$ & Sgt. Baik \\
& $81,6<\bar{X} \leq 100,80$ & Baik \\
RPP & $62,40<\bar{X} \leq 81,60$ & Cukup Baik \\
& $43,20<\bar{X} \leq 62,40$ & Kurang baik \\
& $\bar{X} \leq 43,20$ & Sgt. Kurang \\
& $\bar{X}>84,00$ & Sgt. Baik \\
& $68,00<\bar{X} \leq 84,00$ & Baik \\
LKS & $52,00<\bar{X} \leq 68,00$ & Cukup Baik \\
& $36,00<\bar{X} \leq 52,00$ & Kurang baik \\
& $\bar{X} \leq 36,00$ & Sgt. Kurang \\
\hline
\end{tabular}

Tabel 5. Kategori Penilaian Kevalidan Instrumen

\begin{tabular}{ccc}
\hline Komponen & Interval & Kategori \\
\hline \multirow{4}{*}{ Tes } & $\bar{X}>54,60$ & Sangat Baik \\
& $4420<\bar{X} \leq 54,60$ & Baik \\
& $33,80<\bar{X} \leq 44,20$ & Cukup Baik \\
& $23,40<\bar{X} \leq 33,80$ & Kurang Baik \\
& $\bar{X} \leq 23,40$ & Sgt. Kurang \\
& $\bar{X}>42$ & Sangat Baik \\
& $34<\bar{X} \leq 42$ & Baik \\
Minat & $26<\bar{X} \leq 34$ & Cukup Baik \\
& $18<\bar{X} \leq 26$ & Kurang Baik \\
& $\bar{X} \leq 18$ & Sgt. Kurang \\
\hline
\end{tabular}

Analisis kepraktisan perangkat pembelajaran digunakan untuk mengetahui sejauh mana perangkat pembelajaran yang telah dikembangkan memenuhi kriteria praktis. Kepraktisan dari perangkat pembelajaran ini ditinjau dari hasil lembar penilaian kepraktisan oleh guru, lembar penilaian kepraktisan oleh siswa. Perangkat pembelajaran yang dikembangkan dikatakan telah memenuhi kriteria kepraktisan berdasarkan penilaian guru dan siswa jika minimal berada pada kriteria "baik".

Tabel 6. Kategori Penilaian Kepraktisan oleh Guru

\begin{tabular}{ccc}
\hline \multicolumn{2}{c}{ Interval } & \multirow{2}{*}{ Kategori } \\
\hline RPP & LKS & \\
\hline $\bar{X}>42,00$ & $\bar{X}>37,80$ & Sangat Baik \\
$34,00<\bar{X} \leq$ & $30,60<\bar{X} \leq$ & Baik \\
42,00 & 37,80 & \\
$26,00<\bar{X} \leq$ & $23,40<\bar{X} \leq$ & Cukup Baik \\
34,00 & 30,60 & \\
$18,00<\bar{X} \leq 26,00$ & $16,20<\bar{X} \leq$ & Kurang Baik \\
& 23,40 & \\
$\bar{X} \leq 18,00$ & $\bar{X} \leq 16,20$ & Sangat Kurang \\
\hline
\end{tabular}

Tabel 7. Kategori Penilaian Kepraktisan oleh siswa

\begin{tabular}{cc}
\hline Interval & Kriteria \\
\hline $\bar{X}>37,80$ & Sangat Baik \\
$30,60<\bar{X} \leq 37,80$ & Baik \\
$23,40<\bar{X} \leq 30,60$ & Cukup Baik \\
$16,20<\bar{X} \leq 23,40$ & Kurang Baik \\
$\bar{X} \leq 16,20$ & Sangat Kurang Praktis \\
\hline
\end{tabular}

Analisis keefektifan perangkat pembelajaran digunakan untuk mengetahui sejauh mana perangkat pembelajaran yang dikembangkan memenuhi kriteria efektif berdasarkan hasil tes prestasi dan angket minat. Perangkat pembelajaran efektif ditinjau dari prestasi apabila persentase banyaknya siswa secara klasikal yang memenuhi Kriteria Ketuntasan Minimal (KKM) adalah $\geq 75 \%$. Sedangkan perangkat pembelajaran dikatakan efektif ditinjau dari minat siswa apabila minimal $80 \%$ siswa mencapai kategori tinggi.

\section{HASIL DAN PEMBAHASAN}

Tahapan pengembangan 4-D yang dilakukan pada penelitian ini meliputi define, design dan develop. Tahap define (pendefinisian) diawali dengan analisis awal akhir, analisis karakteristik siswa, analisis konsep, analisis tugas, dan spesifikasi tujuan pembelajaran. Beberapa hal yang diidentifikasi dalam analisis awal-akhir setelah peneliti mengadakan observasi dan wawancara dengan kepala sekolah dan guru diantaranya: (1) proses pembelajaran yang masih didominasi oleh guru dan siswa hanya mendengar dan mencatat penjelasan dari guru. Hal ini tentunya mengakibatkan suasana pembelajaran 
yang cenderung monoton dan tidak mendukung siswa untuk terlibat secara aktif dalam pembelajaran; (2) guru menyajikan materi dengan memberikan contoh-contoh bagaimana mengerjakan suatu soal secara jelas dan rinci. Kemudian, siswa diminta mengerjakan soal-soal yang sejenis sehingga siswa hanya cenderung menerima, menghafal rumus dan konsep; (3) guru dalam menyampaikan materi masih bersifat abstrak, kurang menggunakan benda-benda manipulatif dalam mengkonkritkan materi; (4) beberapa siswa kurang tertarik terhadap pelajaran matematika, bahkan lebih sering berbicara dengan teman; (5) LKS yang digunakan di sekolah hanya berisi ringkasan materi dan kumpulan soal-soal. Hasil analisis karakteristik siswa diperoleh dari pengamatan yang dilakukan peneliti terhadap siswa SMP Negeri 6 Satu Atap Kepil yang berlokasi di Kabupaten Wonosobo, Kecamatan Kepil sebagian besar siswa masih belum dapat berpikir secara abstrak. Untuk itu menggunakan masalah realistik atau konteks yang dapat dibayangkan oleh siswa diharapkan siswa dapat membangun pengetahuannya sendiri.

Tahap design (perancangan) terdiri dari tiga tahapan yaitu pemilihan media, pemilihan format dan rancangan awal. Dalam tahap ini disusun rancangan awal dari RPP dan LKS dengan materi pokok bangun ruang sisi datar. Hasil rancangan ini selanjutnya disebut draft 1 . Tahap selanjutnya yaitu tahap develop (pengembangan). Draft 1 selanjutnya divalidasi oleh dua ahli. Hasil proses ini diperoleh data mengenai skor kevalidan perangkat dan saran dari ahli. Setelah memperoleh saran dan masukan, perangkat direvisi dan hasil revisi perangkat ini disebut draft 2. Draft 2 selanjutnya melalui tahapan pengembangan yang ke-2 yaitu uji keterbacaan (uji coba terbatas). Uji coba terbatas dilakukan untuk menilai perangkat, khususnya LKS yang dikembangkan. Selanjutnya dilakukan uji coba lapangan untuk mendapatkan data mengenai kepraktisan dan keefektifan perangkat yanng dikembangkan.

Penilaian perangkat pembelajaran yang dikembangkan (RPP dan LKS) dilakukan oleh 2 validator untuk diperiksa dan diberi skor berkaitan dengan kevalidan produk pengembangan. Sedangkan komentar dan saran perbaikan dari validator digunakan peneliti untuk merevisi perangkat pembelajaran yang dikembangkan. Hasil penilaian dari kedua validator menyatakan bahwa perangkat pembelajaran layak dan siap digunakan untuk penelitian. Hasil analisis data validasi RPP dari dua validator seperti pada Tabel 8.

Tabel 8. Hasil Analisis Validasi RPP

\begin{tabular}{ccc}
\hline Validator & Skor Total & Kriteria \\
\hline 1 & 109 & Sangat Baik \\
2 & 93 & Baik \\
Rata-rata & 101 & Sangat Baik \\
\hline
\end{tabular}

Berdasarkan Tabel 5 diketahui bahwa rencana pelaksanaan pembelajaran (RPP) yang dikembangkan memenuhi kriteria sangat baik. Hal ini menunjukkan produk pengembangan berupa RPP dengan pendekatan PMR yang dihasilkan valid sehingga layak untuk diujicobakan di lapangan.

Selain kriteria kevalidan secara keseluruhan seperti yang telah disajikan pada Tabel 8 , dapat diketahui pula kevalidan perangkat pembelajaran yang berupa RPP dengan pendekatan PMR pada setiap aspeknya. Adapun Kriteria kevalidan pada setiap aspek dalam RPP disajikan pada Tabel 9. Kevalidan perangkat pembelajaran juga dinilai dari LKS yang dikembangkan. Hasil analisis data validasi LKS dari dua validator seperti pada Tabel 10. Berdasarkan Tabel 10, diketahui bahwa LKS yang dikembangkan memenuhi kriteria baik. Ini berarti produk pengembangan berupa LKS dengan pendekatan PMR yang dihasilkan valid sehingga layak untuk diujicobakan di lapangan.

Tabel 9. Hasil Analisis Validasi RPP Tiap Aspek

\begin{tabular}{lcc}
\hline \multicolumn{1}{c}{ Aspek Penilaian } & Skor & Kriteria \\
\hline Identitas RPP & 9,5 & Sangat Baik \\
Indikator & 7,5 & Baik \\
Tujuan Pembelajaran & 9 & Sangat Baik \\
Sumber Belajar & 12,5 & Baik \\
Media Pembelajaran & 12,5 & Baik \\
Kegiatan Pembelajaran & 38,5 & Sangat Baik \\
Penilaian hasil belajar & 11,5 & Baik \\
\hline
\end{tabular}

Tabel 10. Hasil Analisis Validasi LKS

\begin{tabular}{ccc}
\hline Validator & Skor Total & Kriteria \\
\hline 1 & 93 & Sangat Baik \\
2 & 75 & Baik \\
Rata-rata & 84 & Baik \\
\hline
\end{tabular}

Selain kriteria kevalidan secara keseluruhan seperti yang telah disajikan pada Tabel 10, dapat diketahui pula kevalidan perangkat pembelajaran yang berupa LKS dengan pendekatan PMR pada setiap aspeknya. Kriteria kevalidan perangkat pembelajaran yang berupa LKS pada setiap aspek disajikan pada Tabel 11 . 
Tabel 11. Hasil Analisis Validasi LKS Tiap Aspek

\begin{tabular}{lcc}
\hline \multicolumn{1}{c}{ Aspek Penilaian } & Skor & Kriteria \\
\hline $\begin{array}{l}\text { Kesesuaian isi dan materi } \\
\text { Kesesuaian penyajian dengan }\end{array}$ & 41 & Baik \\
$\begin{array}{l}\text { pendekatan PMR } \\
\begin{array}{l}\text { Kesesuaian dengan syarat } \\
\text { konstruksi (kebahasaan) }\end{array}\end{array}$ & 54 & Baik \\
$\begin{array}{l}\text { Kesesuaian dengan syarat } \\
\text { teknis (kegrafikaan) }\end{array}$ & 34 & $\begin{array}{c}\text { Baik } \\
\text { Sangat } \\
\text { Baik }\end{array}$ \\
\hline
\end{tabular}

Berdasarkan penilaian yang dilakukan oleh ahli, dapat disimpulkan bahwa produk akhir perangkat pembelajaran dengan pendekatan PMR yang terdiri atas RPP dan LKS masingmasing telah valid. Perangkat pembelajaran pada materi bangun ruang isi datar juga telah direvisi berdasarkan masukan atau saran dari ahli sehingga layak untuk digunakan.

Uji coba terbatas merupakan uji coba keterbacaan LKS yang telah divalidasi dan direvisi sesuai masukan atau saran perbaikan. Uji coba tahap ini diberikan kepada beberapa siswa di kelas IX SMPN 6 Satu Atap Kepil yang mewakili siswa berkemampuan tinggi, sedang, dan rendah masing-masing 2 siswa. Keenam siswa tersebut diminta untuk memahami dan membaca LKS yang dikembangkan selanjutnya diminta untuk memberikan penilaian dan masukan atau saran perbaikan mengenai LKS dengan mengisi lembar keterbacaan siswa. Penilaian siswa pada uji coba terbatas ini menyatakan bahwa: (1) Petunjuk dalam LKS sudah cukup jelas; (2) Bahasa yang digunakan mudah dipahami; (3) Gambar, tulisan, dan tampilan LKS menarik; (4) Jenis tulisan dan ukuran dalam LKS sudah jelas, (5) Kegiatan yang akan dilakukan cukup jelas.

Hasil tahap implementasi pada uji coba lapangan ini adalah data hasil penilaian kepraktisan oleh guru, hasil penilaian kepraktisan oleh siswa, hasil tes, dan hasil angket minat siswa. Data hasil penilaian kepraktisan oleh guru dan siswa digunakan untuk mengetahui kepraktisan perangkat pembelajaran yang dikembangkan. Data hasil tes dan hasil angket rasa ingin tahu siswa digunakan untuk mengetahui keefektifan perangkat pembelajaran (RPP dan LKS) dengan pendekatan PMR yang dikembangkan.

Data penilaian kepraktisan oleh guru diperoleh dari hasil penilaian yang dilakukan guru setelah menggunakan perangkat pembelajaran dengan pendekatan PMR dalam pembelajaran matematika. Penilaian kepraktisan oleh guru meliputi penillaian terhadap rencana pelaksanaan pembelajaran (RPP) dan lembar kegiatan siswa (LKS) yang telah digunakan. Adapun rekapitulasi hasil penilaian kepraktisan oleh guru disajikan pada Tabel 12.

Tabel 12. Hasil Analisis Kepraktisan Berdasarkan Penilaian Guru

\begin{tabular}{ccc}
\hline Aspek Penilaian & Skor & Kriteria \\
\hline RPP & 39 & Sangat Baik \\
LKS & 43 & Sangat Baik \\
Rata-rata & 41 & Sangat Baik \\
\hline
\end{tabular}

Data pada Tabel 12 menunjukkan bahwa perangkat pembelajaran yang dikembangkan masuk dalam kriteria sangat baik. Oleh karena itu, perangkat pembelajaran yang dikembangkan dikatakan praktis.

Sedangkan pengambilan data penilaian kepraktisan oleh siswa dilakukan setelah siswa menggunakan LKS dengan pendekatan PMR selama pembelajaran. Rekapitulasi hasil penilaian kepraktisan oleh siswa disajikan pada Tabel 13.

Tabel 13. Hasil Analisis Kepraktisan Berdasarkan Penilaian Siswa

\begin{tabular}{ccc}
\hline Skor Total & Rata-rata & Kriteria \\
\hline 776 & 36,95 & Baik \\
\hline
\end{tabular}

Berdasarkan data pada Tabel 13 menunjukkan bahwa penilaian rata-rata siswa terhadap LKS dengan pendekatan PMR yang dikembangkan berada pada kriteria baik. Dengan demikian, perangkat pembelajaran yang dikembangkan memenuhi kriteria praktis. Berdasarkan hasil analisis data penilaian kepraktisan oleh guru dan angket respon siswa dapat disimpulkan bahwa perangkat pembelajaran dengan pendekatan PMR berupa RPP dan LKS pada materi bangun ruang sisi datar yang diujicobakan memenuhi kriteria praktis sehingga layak untuk digunakan.

Keefektifan perangkat pembelajaran dalam penelitian ini ditinjau dari hasil tes dan angket minat siswa. Data hasil tes dan angket kemudian dianalisis berdasarkan kriteria keefektifan yaitu banyak siswa yang mencapai KKM sekolah minimal $75 \%$ dan hasil angket minat siswa dengan kategori minimal tinggi mencapai $80 \%$. Hasil analisis tes dapat dilihat pada Tabel 14.

Tabel 14. Data Ketuntasan Tes Prestasi

\begin{tabular}{ccc}
\hline $\begin{array}{c}\text { Banyak siswa } \\
\text { mencapai KKM }\end{array}$ & $\begin{array}{c}\text { Nilai } \\
\text { Rata-rata }\end{array}$ & $\begin{array}{c}\text { Persentase } \\
\text { Ketuntasan }\end{array}$ \\
\hline 17 & 78,57 & $80,95 \%$ \\
\hline
\end{tabular}

Berdasarkan Tabel 14, telihat bahwa persentase ketuntasan belajar siswa secara klasikal 
yang mencapai KKM lebih dari $75 \%$. Hasil angket minat siswa dapat dilihat pada Tabel 15.

Tabel 15. Data Angket Minat

\begin{tabular}{cccc}
\hline $\begin{array}{c}\text { Skor } \\
\text { Rata- } \\
\text { rata }\end{array}$ & $\begin{array}{c}\text { Banyak } \\
\text { Siswa }\end{array}$ & $\begin{array}{c}\text { Banyak Siswa } \\
\text { mencapai } \\
\text { minimal pada } \\
\text { kategori tinggi }\end{array}$ & Persentase \\
\hline 91,19 & 21 & 2 & $85,71 \%$ \\
\hline
\end{tabular}

Berdasarkan data pada Tabel 15, terlihat bahwa skor rata-rata angket minat siswa dalah 91, 91 berada pada kategori tinggi dan $85,71 \%$ siswa berada pada kategori tinggi. Sehingga dapat disimpulkan bahwa perangkat pembelajaran yang dikembangkan telah memenuhi kriteria efektif.

Pengembangan perangkat pembelajaran dalam penelitian ini telah dilakukan melalui tahapan 4-D. Melalui tahapan tersebut, peneliti dapat mengetahui kualitas perangkat pembelajaran yang dikembangkan. Menurut Nieven (1999, p.126), produk pengembangan yang berkualitas harus memenuhi kriteria kevalidan, kepraktisan, dan keefektifan. Oleh karena itu, berdasarkan hasil validasi ahli dan uji coba lapangan diketahui bahwa perangkat pembelajaran yang dikembangkan telah memenuhi kriteria valid, praktis, dan efektif ditinjau dari minat dan prestasi belajar siswa. Berdasarkan hasil validasi yang dilakukan oleh ahli yang berkompeten maka diperoleh komentar dan masukan agar produk yang dikembangkan mencapai kriteria valid. Setelah dilakukan beberapa perbaikan, maka perangkat pembelajaran yang dihasilkan yang terdiri dari RPP, LKS, dan Instrumen penilaian dinyatakan telah mencapai kriteria valid. Sehingga berdasarkan hasil validasi oleh beberapa ahli, perangkat pembelajaran yang dihasilkan sudah layak digunakan setelah dilakukan revisi terlebih dahulu.

Berdasarkan hasil uji coba terbatas dan uji coba lapangan dapat diketahui bahwa perangkat yang dihasilkan telah mencapai kriteria praktis. Kepraktisan diukur dari penilaian kepraktisan oleh guru dan siswa. Penilaian kepraktisan dari guru dan siswa menunjukkan bahwa perangkat pembelajaran yang dikembangkan mencapai kriteria praktis. Kriteria praktis dapat dicapai karena produk yang dikembangkan sesuai dengan komponen-komponen dan langkah-langkah pembelajaran dengan pendekatan pendidikan matematika realistik, sehingga siswa terlibat langsung secara aktif dalam pembelajaran.

Berdasarkan hasil uji coba lapangan dapat diketahui bahwa perangkat pembelajaran yang dihasilkan telah mencapai kriteria efektif. Ke- efektifan diukur dari ketuntasan siswa dalam tes. Selain itu juga dilihat dari hasil angket minat siswa. Hasil dari angket minat siswa menunjukkan bahwa minat siswa bearada pada kategori tinggi. Hal ini, disebabkan oleh LKS yang dikembangkan memuat kegiatan-kegiatan yang melibatkan peran aktif siswa untuk membangun pengetahuannya sendiri. Dengan melakukan kegiatan, siswa menjadi tertarik untuk belajar matematika. Selain itu desain LKS yang menarik dengan ilustrasi gambar dan LKS yang berwarna juga membuat siswa tertarik untuk membaca. Sedangkan hasil dari analisis tes menunjukkan bahwa 80,95\% mencapai KKM. Berdasarkan hasil tersebut dapat disimpulkan bahwa perangkat pembelajaran dikatakan efektif.

RPP yang dikembangkan oleh peneliti bertujuan untuk memudahkan guru dalam menerapkan langkah-langkah pembelajaran dengan menggunakan pendekatan pendidikan matematika realistik. Karakteristik yang dikembangkan adalah yaitu: (1) masalah yang digunakan dalam kegiatan pembelajaran merupakan masalah kontekstual, (2) Kegiatan pembelajaran dirancang dengan mengacu pada prinsip-prinsip dan karakteristik pendidikan matematika realistik yaitu memahami masalah kontekstual, mengembangkan model/skema, pemanfaatan hasil kontruksi, interaktivitas dan keterkaitan, (3) kegiatan pembelajaran dirancang untuk memaksimalkan peran guru sebagai fasilitator. Salah satu bentuk perwujudan dari peran guru sebagai fasilitator adalah dengan memantau proses diskusi kelompok/ kelas serta memberikan pertanyaan-pertanyaan arahan kepada siswa jika siswa menemui kesulitan, (4) Kegiatan pembelajaran dirancang untuk menumbuhkan minat siswa. Kegiatan ini diwujudkan dengan aktivitas siswa dalam kegiatan diskusi kelompok maupun diskusi kelas. Selain dengan mempresentasikan hasil penyelesaian masalah yang dilakukan, siswa juga dilatih aktif menanggapi presentasi atau mengajukan pertanyaan.

Selain RPP, penelitian ini juga mengembangkan LKS yang bertujuan sebagai panduan guru dan siswa dalam melakukan kegiatan pembelajaran, sebagai lembar aktivitas siswa yang memfasilitasi kegiatan diskusi serta sarana untuk menumbuhkan minat siswa. Karakteristik LKS yang dikembangkan adalah sebagai berikut: (1) Memuat secara eksplisit langkah-langkah pembelajaran dengan pendekatan pendidikan matematika realistik. Langkah-langkah pembelajaran tersebut antara lain: memahami masalah kontekstual, mendeskripsikan masalah kontekstual, 
menyelesaikan masalah kontekstual, membandingkan dan mendiskusikan jawaban, menyimpulkan, (2) Berisi aktivitas-aktivitas yang memfasilitasi siswa untuk membangun pemahaman/ pengetahuan mereka sendiri tentang materi yang diajarkan yang diwujudkan dalam aktivitasaktivitas penemuan konsep, (3) Alur aktivitas dalam LKS dirancang untuk menumbuhkan minat siswa yang diwujudkan dengan menyajikan masalah kontekstual yaitu masalah yang dekat dengan kehidupan sehari-hari atau yang dapat dibayangkan oleh siswa, (4) Soal latihan dalam LKS merupakan soal pengaplikasian konsep yang telah dipelajari.

\section{SIMPULAN}

Berdasarkan hasil penelitian dan pembahasan diperoleh simpulan sebagai berikut: (1) Produk perangkat pembelajaran matematika dengan pendekatan pendidikan matematika realistik pada materi bangun ruang sisi datar yang dikembangkan terdiri dari RPP dan LKS memenuhi kriteria valid berdasarkan validasi ahli sehingga layak untuk digunakan. Hal ini ditunjukkan dari hasil penilaian RPP memenuhi kriteria valid yaitu berada pada kategori sangat baik dengan skor 101. LKS memenuhi kriteria valid yaitu barada pada kategori baik dengan skor 84, (2) Produk perangkat pembelajaran matematika dengan pendekatan pendidikan matematika realistik pada materi bangun ruang sisi datar yang dikembangkan terdiri dari RPP dan LKS memenuhi kriteria praktis berdasarkan hasil penilaian kepraktisan oleh guru dan siswa. Hal ini ditunjukkan dari hasil penilaian RPP dan LKS oleh guru berada pada kategori sangat praktis dengan skor masing-masing 39 dan 43, sedangkan dari hasil penilaian siswa LKS berada pada kategori praktis dengan skor 36,95, (3) Produk perangkat pembelajaran matematika dengan pendekatan pendidikan matematika realistik pada materi bangun ruang sisi datar yang dikembangkan terdiri dari RPP dan LKS memenuhi kriteria efektif jika ditinjau dari minat dan prestasi belajar siswa. Hasil penelitian menunjukkan hasil skor rata-rata angket minat secara klasikal berada pada kategori tinggi yaitu 91,29 dan $85,71 \%$ siswa berada pada kategori tinggi. Untuk prestasi belajar $80,95 \%$ siswa telah mencapai KKM.

Berdasarkan penelitian yang telah dilaksanakan dan simpulan yang diperoleh, maka saran pemanfaatan produk yang dikembangkan adalah sebagai berikut: (1) Produk perangkat pembelajaran matematika dengan pendekatan pendidikan matematika realistik berorientasi pada minat dan prestasi belajar siswa yang dikembangkan telah memenuhi kategori valid, praktis, dan efektif sehingga dapat dijadikan sebagai salah satu alternatif perangkat pembelajaran yang dapat digunakan dalam pembelajaran matematika. Perangkat pembelajaran ini dapat dijadikan referensi atau pedoman bagi guru untuk mengembangkan perangkat pembelajaran yang serupa pada materi atau pelajaran lain. (2) Perangkat pembelajaran yang dihasilkan dari penelitian ini belum banyak memunculkan salah satu karakteristika PMR, yaitu keterkaitan. Oleh karena itu, perlu dipikirkan pengembangan perangkat pembelajaran yang memunculkan semua karakteristik PMR. (3) Untuk penelitian pengembangan perangkat pembelajaran selanjutnya hendaknya mengatur durasi waktu pengerjaan LKS.

\section{DAFTAR PUSTAKA}

BNSP. (2015). Laporan hasil ujian nasional tahun ajaran 2014/2015. Jakarata: BNSP.

Cowan, P. (2006). Teaching mathematics: A handbook for primay and secondary school teachers. New York, NY: Routledge.

Elliott, S. N., Kratochwill, T. R., Cook, J. L., \& Travers, J. F. (2000). Educational psychology: Effective teaching effective learning $\left(3^{\text {rd }}\right.$ ed.). Boston, MA: Mc Graw Hill.

Frenzel, A.C., Goetz. T., Pekrun, R., \& Watt, H. M. G. (2010). Development of mathematics interest in adolescence: Influence of gender, family, and school context. Journal of Research on Adolescence, 20(2), 507-537.

Gravemeijer, K. P. E. (1994). Developing realistic mathematics education. Utrecht, Netherland: CD- $\beta$ Press.

Haylock, D., \& Thangata, F. (2007). Key concept in teaching primary mathematics. Singapore: SAGE Publication.

Mendiknas. (2006). Peraturan Menteri Pendidikan Nasional RI Nomor 22, Tahun 2006, tentang Standar Isi Pendidikan Dasar dan Menengah.

Mendikbud. (2014). Peraturan Menteri Pendidikan dan Kebudayaan Nomor 58 Tahun 2014, tentang Kurikulum SMP.

Mullis, I. V., Martin, M.O., Foy. P., \& Arora, A. (2012). TIMSS 2011 international results 
Pythagoras, 13 (1), 2018 - 87

Ivone Marlinda, Ariyadi Wijaya

in mathematics. Chessnut Hill, PA: TIMSS \& PIRLS International Study Center Lynch School of Education, Boston College.

Nitko, A. J., \& Brookhart, S. M. (2011). Educational assesment of student. Upper Saddle River, NJ: Pearson Education.

Nugraheni, E., \& Sugiman, S. (2013). Pengaruh pendekatan PMRI terhadap aktivitas dan pemahaman konsep matematika siswa SMP. PYTHAGORAS: Jurnal Pendidikan Matematika, $\quad 8(1), \quad$ 101-108. doi:10.21831/pg.v8il.8498

Schunk, D. H., Pintrich, P. R., \& Meece, J. R. (2010). Motivation in education: Theory, research and application. London, England: Pearson Education International.

Sembiring, R. K. (2010). Pendidikan matematika realistik Indonesia (PMRI): Perkembangan dan tantangannya. IndoMS Journal of Mathematics Education, 1(1), 11-16.

Sugiman, S. \& Kusumah, Y. S. (2010). Dampak pendidikan matematika realistik terhadap peningkatan kemampuan pemecahan masalah matematika siswa SMP. IndoMS Journal of Mathematics Education, 1(1), 41-45.

Thiagarajan S., Semmel, D., \& Semmel, M. I. (1974). Instructional development for training teachers of exceptional children: A sourcebook. Minneapolis, MA: Central for Innovation on Teaching the Handicaped.
Van den Heuvel-Panhuizen, M. (1996). Assessment and realistic mathematics education. Utrecht, Netherland: CD- $\beta$ Press.

Van den Heuvel-Panhuizen, M. (2001). Realistic mathematics education as work in progress. Proceedings of 2001 the Netherlands and Taiwan conference on mathematics education, Taipe, Taiwan, 19-23 November, 1-43.

Webb, D. C., Van der Kooij, H., \& Geist, M. R. (2011). Design research in the Netherland: Introducing logarithms using realistic mathematics education. Journal of Mathematics Education at Teacher College, 2(1), 47-52.

Widoyoko, E. P. (2009). Evaluasi program pembelajaran panduan praktis bagi pendidik dan calon pendidik. Yogyakarta: Pustaka Pelajar.

Zaini, A., \& Marsigit, M. (2014). Perbandingan keefektifan pembelajaran matematika dengan pendekatan matematika realistik dan konvensional ditinjau dari kemampuan penalaran dan komunikasi matematik siswa. Jurnal Riset Pendidikan Matematika, 1(2), 152-163. doi:10.21831/jrpm.v1i2.2672

Zulkardi, Z. (2002). Developing a learning environmenton realistic mathemathics education for Indonesian student teachers. Tesis Master, tidak diterbitkan. Enschede, Netherlands: University of Twente. 